\section{Innovation performance in service companies and KIBS vis-à-vis manufacturing: the relevance of absorptive capacity and openness}

\author{
Aurora A. C. Teixeira 123 \\ ${ }^{1}$ University of Porto, School of Economics, Porto, Portugal \\ ${ }^{2}$ Center for Economics and Finance - CEF, University of Porto, Porto, Portugal \\ ${ }^{3}$ Centre of Economics and Fraud Management-OBEGEF, Porto, Portugal
}

\section{Lilian Bezerra}

University of Porto, School of Economics, Porto, Portugal
Received on

10/18/2014

Approved on

04/11/2016

\section{Responsible editor:}

Prof. Dr. João Maurício Gama

Evaluation process:

Double Blind Review

\begin{abstract}
Purpose - The present paper adds to the most recent current of literature that highlights the importance of innovation in services, analyzing a setting - Portugal - which is relatively backward in terms of innovation performance.
\end{abstract}

Design/methodology/approach - Based on a sample of 4128 companies (including 1489 service companies) that answered the Community Innovation Survey 2008, we assessed, by resorting to logistic regressions, the determinants of innovation performance in Portuguese companies.

Findings - 1) Workers who have the 1 st cycle of higher education have a positive and significant impact on the innovation of service companies whereas $\mathrm{PhDs}$ are detrimental to companies' innovative performance; 2) Companies in the service sector in general, and in KIBS in particular, that effectively invest in external and (continuous) internal R\&D activities are more innovative; 3) External scientific sources of information for innovation are crucial (and much more than in manufacturing) to the innovation performance of service companies, especially of KIBS; 4) Similarly to manufacturing, participation in innovation activities in cooperation with foreign partners appears as a key factor in the innovative performance of service companies.

Originality/value - The study demonstrates the influence of companies' openness and the relative importance attributed to different sources of information for innovation on innovation outcomes of service companies (and KIBS) compared to manufacturing industries.

Keywords - Innovation performance; Services; KIBS; Manufacturing; Portugal.

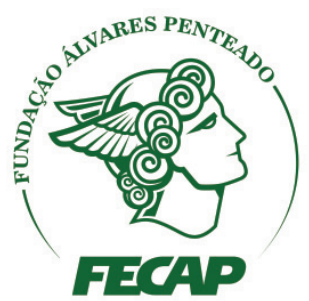

Review of Business Management

DOI: $10.7819 /$ rbgn.v18i59.2215 


\section{Introduction}

Services and innovation have characterized the recent growth of world economies (Aboal, Bravo-Ortega, \& Cresp, 2015; Battisti, Gallego, Rubalcaba, \& Windrum, 2015). Against this backdrop, the service sector (significant, especially in developed economies) and innovation (the acknowledged engine of economic growth) emerge as a research field with an increasing highprofile and relevance (Djellal, Gallouj, \& Miles, 2013; Lazzarotti, Manzini, Nosella, \& Pellegrini, 2016). However, despite the growing importance of the service sector in developed economies (Castro, Montoro-Sanchez, \& Criado, 2011; Crevani, Palm, \& Schilling, 2011; Czarnitzski \& Spielkamp, 2003; Un \& Montoro-Sanchez, 2010), studies on innovation in this sector have only gained impetus in the last 20 years (Bryson \& Monnoyer, 2002; Castellacci, 2010; Gallego, Rubalcaba, \& Hipp, 2013a; Gallego, Rubalcaba, \& Suarez, 2013b). Until then, they were focused mostly on (tangible) products and the industrial sector (Bryson \& Monnoyer, 2002; Castro et al., 2011; Droege, Hildebrand, \& Forcada, 2009; Toivonen \& Tuominen, 2009; Un \& MontoroSanchez, 2010), services being regarded as the "laggards" as far as innovation was concerned (Camacho \& Rodríguez, 2005; Droege et al., 2009; Gallouj \& Savona, 2009). The specificities and heterogeneity of this sector were some of the arguments used for innovation in services to not be recognized at all (Gallouj, 2002a, 2002b; Gallouj, Weber, Stare, \& Rubalcaba, 2015).

The arrival of Information and Communication Technologies seems to be the turning point of this backdrop (Nardelli, 2015), in which services were no longer seen merely as "laggards" or "passive recipients" of technology arising mainly from the manufacturing industry, but as nuclear, i.e., as the engine of the new knowledge-based economy (Gallouj \& Savona, 2009). Recent studies confirm that not only are services more innovative than we imagined (Castro et al., 2011) but, in some fields, they are more innovative than the manufacturing industry average (Cáceres \& Guzmán, 2014; Gallego, Gutiérrez, \& Taborda, 2015; Organization for Economic Co-operation and Development [OECD], 2005a), having a crucial and multivariate role in the current economy as providers, users, precursors and intermediaries in the innovation process (Battisti et al., 2015; Czarnitzski \& Spielkamp, 2003).

Since the boundaries between products and services, between tangible and intangible products are increasingly subtle (Gallouj \& Savona, 2009; Vergori, 2014), the advancement of research on innovation in services in order to better understand and characterize its nature has led to the emergence of studies on innovation in services, alone or in comparison with other sectors of activity, particularly the manufacturing industry (Carlborg, Kindström, \& Kowalkowski, 2014).

Nonetheless, facing the increased attention received by innovation in services over recent years (see den Cáceres \& Guzmán, 2014; Hertog, Aa, \& Jong, 2010; Rubalcaba, Gago, \& Gallego, 2010), López and Ramos (2015) argue that further research is needed to gain a better understanding of the nature, determinants, and effects of innovation processes in services.

Indeed, there is still a reasonable ambiguity of results achieved to date in this field. Some studies demonstrate that service sector is as innovative as the manufacturing sector - for instance, Álvarez, Bravo-Ortega and Zahler (2015), which analysed 7192 Chilean companies, Carvalho, Costa and Caiado (2013) that focused on 4504 Portuguese companies, Evangelista and Vezzani (2010) and Sirilli and Evangelista (1998) that examined Italian companies, or Forsman (2011) which explored the types of innovations developed in small Finnish manufacturing and service companies. Other studies found evidence that service companies have low propensity to innovate (López \& Ramos, 2015), and fall behind their manufacturing counterparts as to innovation performance (Tacsir, 2011; Zahler, Iacovone, \& Mattoo, 2014). In sharp contrast with the latter set of studies, Gallego et al. (2015), analyzing 
7765 companies from Colombia, concluded that service companies, regardless the type of innovation, innovate more than manufacturing companies.

Additionally, some determinants of the innovative performance of service companies, as compared to manufacturing companies or the Knowledge Intensive Business Services (KIBS) sub-set, demand further exploration (Djellal et al., 2013), particularly in what concerns the relation between companies' absorptive capacity, openness with scientific, market, and other partners, and innovation performance (see Lazzarotti et al., 2016). In this context, the present paper contributes to empirical literature on the innovative performance of service companies, at three main levels.

Firstly, human capital, as a key component of companies' absorptive capacity (Cohen \& Levinthal, 1990), is accounted considering its heterogeneity in terms of education levels (see Becker, 1983). Human capital provides a competitive advantage for companies and is an essential part of innovation (McGuirk, Lenihan, \& Hart, 2015). However, the bulk of empirical research in the field fails to take explicitly into account the heterogeneity of human capital, namely in terms of education levels (Crook, Todd, Combs, \& Woehr, 2011). Nearly all studies proxy human capital as the proportion of highly educated (Czarnitzki \& Spielkamp, 2003; Moreira, Silva, Simóes, \& Sousa, 2012; Pires, Sarkar, \& Carvalho, 2008) or skilled (Gallego et al., 2015) workers. To the best of our knowledge, no study has yet assessed whether highly educated workers with distinct levels of education (undergraduates, masters, PhDs) distinctly impact companies' innovative performance and whether this potential differentiated impact occurs similarly in service and manufacturing industries. The rise of a more knowledge-based economy can render $\mathrm{PhD}$ individuals, who are trained to conduct research, critical elements in the creation, commercialization and diffusion of innovation (Garcia-Quevedo, Mas-Verdu, \& Polo-Otero, 2012; Herrera \& Nieto, 2015). Nonetheless, in
Europe (and in Portugal specifically), companies often prefer to employ highly educated individuals without doctoral degrees (i.e., undergraduates or master), as they consider those with a doctoral degree to be too specialized or with a mindset not matching the business rationality (Barroca, Meireles, \& Neto, 2015). The clarification of such a debate is a challenging and pertinent task.

Secondly, we explicitly address the overlooked issue of $\mathrm{R} \& \mathrm{D}$ persistence. The literature is almost unanimous in recognizing the relevance in-house/intramural Research and Development (R\&D) activities for the innovative performance of companies (both service and manufacturing) (see Carvalho, Costa, \& Caiado, 2013; Pires et al., 2008). Recently, however, Leiponen (2012) and Añón Higón (2016) uncovered that it is the regularly performed $\mathrm{R} \& \mathrm{D}$, rather than just performed $\mathrm{R} \& \mathrm{D}$, that is a critical determinant for the innovation performance of respectively, Finnish and Spanish companies. We complement the studies of Pires, Sarkar and Carvalho (2008) and Carvalho et al. (2013), which analyzed the determinants of innovation of Portuguese service and manufacturing companies (respectively, for the periods 1998-2000 and 2002-2004), by assessing, for a more recent period (20062008), the role of continuing intramural R\&D on (service) companies innovative performance.

Thirdly, we fill a research gap by investigating whether the companies' openness and the relative importance attributed to the distinct sources of information for innovation (most notably, market - clients, suppliers and competitors; scientific - e.g., universities and other science and technology organizations, and others - e.g., exhibitions and trade fairs, industry associations) influence innovation outcomes similarly in service (and, within it, in KIBS) and manufacturing industries. Despite external research being regarded as a key strategic concern to global economy, the patterns of innovative research have been mainly explored in the manufacturing setting (Leiponen, 2012; Marin \& Bermejo, 2015). Focusing on Portuguese service companies, Janeiro, Proença 
and Gonçalves (2013) empirically assessed which factors influenced the collaboration of companies with universities for innovation related activities. However, the influence that this and other external sources of information for innovation have on the innovative performance of service companies was not investigated. We address this gap by considering scientific, market, and others sources of information for innovation, and the number of external and foreign entities with whom companies cooperate for innovation, as innovation determinants.

Using a database with 4128 companies -1489 from services (614 of which KIBS) and 2639 from manufacturing - located in Portugal that answered the Community Innovation Survey 2008, covering the innovation activities in the three-year period 2006-2008, we analyze econometrically the key innovation determinants of service and KIBS vis-à-vis manufacturing companies.

The structure of this study is as follows. The next section presents the review of literature on the determinants of innovation in Services. Section 3 shows the methodology of analysis and how CIS-2008 data is accessed and processed. Data analysis and the presentation of results of the estimation of models are shown in detail in Section 4. Finally, the Conclusion discusses the results obtained in light of existing literature and summarizes the main conclusions and contributions of this study, indicating directions for future research on the topic under analysis.

\section{The determinants of innovation in services: conceptual framework and main hypotheses to be tested}

\section{I The services regime as relevant analysis framework}

Innovation activities, in both services and manufacturing, are about creating or sourcing relevant knowledge and combining it in new and valuable ways (Leiponen, 2012). But, as Vergori (2014, p. 147) says, "the concept of innovation has been traditionally related to the industrial sector."

The understanding of innovation in services has evolved swiftly and significantly (Zahler et al., 2014). Three main approaches can be identified - technologist/assimilation, demarcation/differentiation, and synthesis/ integrative - to disclose which basic assumption on innovation in services takes the lead in contemporary research (De Fuentes, Dutrenit, Santiago, \& Gras, 2015; Djellal et al., 2013; Droege et al., 2009). ${ }^{1}$

Initial contributors to the debate on innovation in services considered the service sector a laggard in terms of innovation, merely 'serving' important sectors in the economy (Barras, 1986). Given the relation established of innovation in services to technological competence gains and progress in information technology in general, Barras' (1986) theory became known as the technologist approach (Gallouj \& Weinstein, 1997). This approach, also known as 'assimilation perspective', argues that services should be measured and evaluated in the same way as manufacturing (technological) innovation (Coombs \& Miles, 2000; Drejer, 2004). In sharp contrast stands the 'demarcation approach', which held that innovation is very dissimilar to services and thus has to be understood and measured in an entirely autonomous way (Djellal \& Gallouj, 2001). More recently, the 'synthesis approach' emerged, focused more on efforts to bring together innovation in services and manufacturing than on studying both fields separately (Coombs \& Miles, 2000; Gallouj \& Weinstein, 1997). In this approach, it is recognised that there are a lot of common factors between manufacturing and services, but also particularities of the services sector which affect the way innovation takes place (Droege et al., 2009; Tether \& Howells, 2007).

Following the contribution by Chang, Linton and Chen (2012), we adopt their 'services regime' approach as the conceptual framework for analyzing the determinants of innovation of service companies. The services regime integrates the synthesis perspective and offers a 
framework that is rather comprehensive due to its consideration of sources of innovation, properties of the knowledge base, and the cumulativeness of (non)technological knowledge. According to the authors, "service firms have patterns of innovation that are best described as loosely coupled systems with diversified sources of innovation [and] multiple innovation trajectories" (Chang et al., 2012, p. 1569).

Our model (and the corresponding hypotheses), depicted in Figure 1, considers innovation as combining multiple trajectories relevant to technological and service innovation (most notably, product, process, organizational and marketing innovation). Grounded on the services regime, it encompasses two main blocks: 1) the knowledge base and the absorptive capacity dimension; and 2) the openness dimension, which includes companies' propensity to cooperate with external/foreign entities and the types of external sources of information for innovation they might rely on.

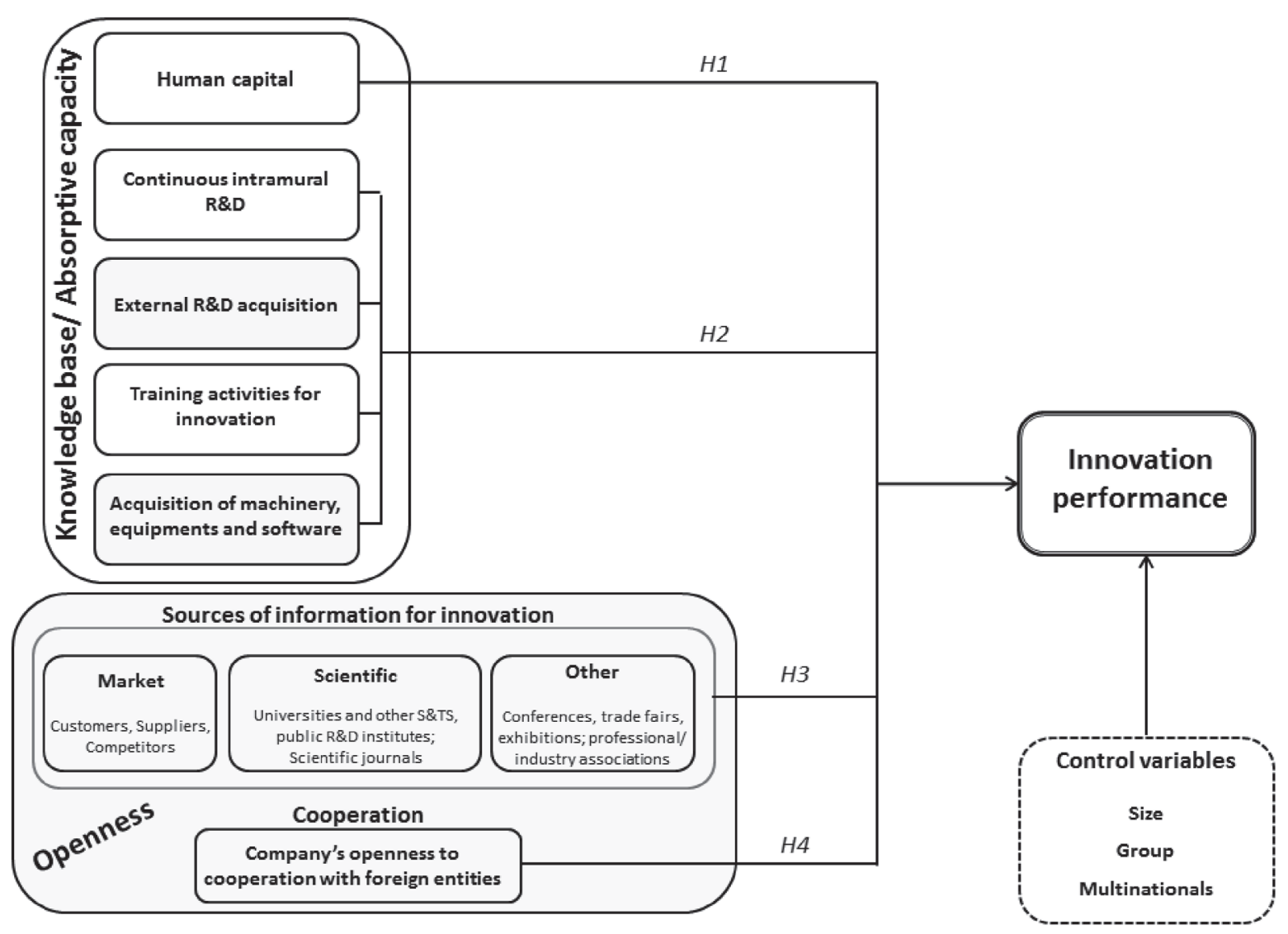

Figure 1. A framework of innovation determinants in service companies

Note. Grey cells identify external knowledge and sources of information; $\mathrm{H}$ identifies the main hypotheses to be tested.

Absorptive capacity, defined originally as a firm's ability to learn from external sources (Cohen \& Levinthal, 1990), includes two capabilities (Zahra \& George, 2002), argued the ability to evaluate and acquire external knowledge, and the ability to exploit this acquired external knowledge.
Such abilities are frequently associated to the several dimensions of human capital (Schneider, Gunther, \& Brandenbury, 2010; Vinding, 2006), internal (intramural) and external R\&D (Battisti et al., 2015), (in-house) training (Leiponen, 2012), and the acquisition of new equipment 
and machinery (Carvalho et al., 2013; Pires et al., 2008). A number of recent studies have called the attention for the issue of persistence in $\mathrm{R} \& \mathrm{D}$ engagement (see García-Quevedo, Pellegrino, \& Vivarelli, 2014), that is, the engagement in $\mathrm{R} \& \mathrm{D}$ activities in a continuous, regular way. Empirical evidence shows that innovation output is significantly determined by innovation input, implying that innovation output persistence should be closely related to innovation input persistence (Máñez, Rochina-Barrachina, SanchisLlopis, \& Sanchis-Llopis, 2015). Studying 533 Finnish companies, Leiponen (2012, p. 1257) found that "contrary to received wisdom, regularly performed R\&D plays an important role in innovation of the set of service industries included in our sample." In a complementary view, it is often argued that, in services, (in-house) training compensates for formal $\mathrm{R} \& \mathrm{D}$ activities, since relevant capabilities in business services reside to a large extent in individuals and teams as opposed to equipment or blueprints (Leiponen, 2012).

Openness reflects how intensively and through which sources a firm collaborates with external actors to enhance its innovation (Lazzarotti et al., 2016). It is often associated to the 'open innovation' model (Chesbrough, 2003) in which external sources of information and knowledge sharing outside the organization are seen as the crucial resources for the development and implementation of innovation, both in services and in manufacturing. Some authors suggest (e.g., Tether \& Tajar, 2008; Uppenberg $\&$ Strauss, 2010) that service companies rely to a larger extent on external sourcing of new knowledge. They further claim that service industries tend to innovate more in interaction with customers, suppliers, competitors or consulting companies. Additionally, Arundel, Kanerva, Cruysen and Hollanders (2007) documented that universities and research institutes are on an average less valued as sources of information or as collaboration partners for service innovators relative to manufacturing innovators. Notwithstanding, López, Astray, Pazos and Calvo (2015) underline that we know little about the role of a service firm's strategy in collaborating with universities (and other scientific related sources).

\subsection{Main hypotheses to be tested}

\subsection{Knowledge base/Absorptive capacity}

In relating the qualifications of the work factor with different types and degrees of innovation in small service and industrial companies located in the United Kingdom, Freel (2005) concluded that service companies that present novel innovation ${ }^{2}$ in the product tend to (significantly) employ more technicians and engineers/scientists, and provide intensive training. Moreover, in the case of service companies, the intensity of training is greatly associated with the novel innovation in the process, and the more innovative companies (whether in services or industry) offer more training to their employees.

Concern for human capital is also a variable of analysis in the studies by $\mathrm{He}$ and Wong (2009) on the KIBS in Singapore, and by Pires et al. (2008) for service and industry companies in Portugal (based on the CIS-3). Both studies adopt a perspective of training and education of human resources, assessing in particular whether company employees are part of training programs or whether they have higher education training.

For He and Wong (2009), KIBS are highly dependent on expertise and skills. In their study, the level of formal education of human resources is positively related to the tendency to innovate in KIBS, especially in terms of product innovation. Nevertheless, there is no significant relationship in training of human resources (neither for product nor process innovation).

In the case of the study by Pires et al. (2008), however, which focuses on Portuguese service companies, the training of human resources has a significantly less impact on innovation in the service sector (both in product ${ }^{3}$ and in process) compared to the industrial companies, while the level of formal education of human resources has a significantly greater 
impact on product innovation, but significantly less in process innovation.

All in all, regarding the companies analyzed, Pires et al. (2008) conclude that human resource training is positive and significant for pioneering and process innovation, while nothing can be said about product innovation. Now, with regard to schooling, this variable is significant and positive only for process innovation, and has no statistical significance in terms of process innovation.

Based also on CIS data (in this case, CIS-4 for Germany, regarding the period 20022004), for service and industrial companies, Schmidt and Rammer (2006) concluded that, for the group of companies studied, the level of schooling of human resources has a significantly positive impact on technological innovation, ${ }^{4}$ but nothing can be said for the non-technological type of innovation. In the same line of thought, Moreira et al. (2012), focusing on the innovative capacity of companies in relation to marketing, and also using CIS- 4 data (for Portuguese service and industrial companies), could not reach a conclusion on the relationship of human capital (through the participation of employees in training activities) with this type of innovation, since this variable was not statistically significant.

The rise of a more knowledge-based economy can render individuals with higher levels of human capital (e.g., undergraduates compared to individuals without higher education degrees; masters compared to undergraduates; PhDs compared to masters) more relevant for companies' innovative performance (GarciaQuevedo et al., 2012; Herrera \& Nieto, 2015). However, the sluggish demand for very highly human capital endowed individuals, namely PhDs, by companies both in Europe and in Portugal (Barroca et al., 2015; Teixeira \& TavaresLehmann, 2014), blurs the role of human capital on companies' innovation.

Notwithstanding this remark, based on the results of existing literature, we conjecture that:
H1: Human capital is positively and significantly associated with innovation

H1a: The strength of impact of human capital differs for the KIBS sector, compared to other service sectors

H1b: The strength of the impact of human capital differs for the services, compared to manufacturing industry

The already cited work by Pires et al. (2008) allows us to 'bridge' over to another important variable associated with companies' absorptive capacity, the acquisition of knowledge. Further to the ability of companies to absorb knowledge (learned by the human resources through formal education, mentioned above), the authors also relate innovation to different forms of knowledge acquisition, described as "knowledgesourcing activities": 1) activities of internal origin (measured by the development of internal R\&D activities) and external origin (measured by the participation in external $\mathrm{R} \& \mathrm{D}$ and cooperative R\&D activities); and 2) knowledge-adoption activities, measured by the purchase of machinery, equipment and software.

Pires et al. (2008) concluded that, in the case of service companies, internal $R \& D$ activities have a significantly greater impact on all types of innovation studied, when compared with the results of the manufacturing industry. Where external sources of knowledge are concerned, the external R\&D activities have a higher and more significant impact on the innovation of products and processes, and were not significant for pioneering innovation, and the cooperative $R \& D$ activities have less significant impact on product and process innovations, being more significant to pioneering innovation (compared to industry). Finally, the purchase of machinery, equipment and software impacts less on process innovation, and there is no evidence in relation to product innovation (pioneering and non-pioneering).

Pires et al. (2008) analyzed a set of companies as a whole and found that the 
external knowledge-sourcing activities (external and cooperative R\&D) are significantly more important to product innovation, whereas the internal sources (internal R\&D) are significantly relevant to process innovation, with the purchase of machinery, equipment and software being relevant in both cases. This data confirms the important role, in the innovative process, played by knowledge and the development of knowledgegenerating activities.

More recently, studying a set of Finnish companies, Leiponen (2012) uncovered that it is the regularly or systematically performed $\mathrm{R} \& \mathrm{D}$, rather than just sporadic R\&D, that is a critical determinant for the innovation performance of service companies. Complementing the studies by Pires et al. (2008) and Carvalho et al. (2013), we consider, instead of the 'intramural' $R \& D$, the role of 'continuing intramural' $\mathrm{R} \& \mathrm{D}$ on companies' innovative performance.

Thus, based on existing literature, we believe that the acquisition of knowledge and the activities thereof (such as continuing $\mathrm{R} \& \mathrm{D}$, training and the purchase of machinery, equipment and software) have a positive effect on the companies' ability to innovate, bringing us to the following working hypothesis:

H2: Knowledge activities (continuing intramural and external R\&D, training and purchase of machinery and equipment) are positively and significantly associated with innovation

H2a: The strength of the influence of knowledge activities differs for the KIBS sector, compared to other service sectors

H2b: The strength of the influence of knowledge activities differs for the services, compared to manufacturing industry

\subsubsection{Openness}

Companies have, over the last few years, shifted their innovation focus from internal sources of information [as know-how and level of schooling of employees] to external sources, such as consumers, universities, suppliers and business partners (Gomes, Kruglianskas, \& Scherer, 2011). However, the topic has been analyzed mainly regarding to suppliers and customers, being scientific sources, such as universities, rather overlooked (Lazzarotti et al., 2016).

Openness gives companies the possibility to expand their knowledge base in order to access advanced technology, new products and processes (Battisti et al., 2015). It fosters access to complementary assets, which might result in the creation and development of resources that would otherwise be hard to assemble and to develop. Additionally, it enables companies to share the innovation risks and costs associated with $\mathrm{R} \& \mathrm{D}$ and reduce developmental process time (West $\&$ Bogers, 2014).

Varis and Littunen (2010) related different types of information sources ${ }^{5}$ with the introduction of different types of innovation (product, process, marketing and organizational) in small and medium Finnish companies (with entrepreneurial characteristics) and concluded that: in terms of product and marketing innovation, there was a positive relationship with "Other external sources of information"; for process innovation, there was a positive relationship with information from "Financial support organizations"; and for organizational innovation, relevant information derived from "Cooperation relationships" and "Regional organization of knowledge." According to the authors, these results corroborate recent studies in this field, suggesting that the introduction of different types of innovation are associated with the use of different types of information sources and collaboration relationships (while noting that, contrary to expectations, a relationship with information sources internal to the company could not be established).

More recently, Robinson and Stubberud (2011) used the CIS-2004 data for Norway to compare the main information sources for innovation (from the point of view of the capacity to absorb knowledge) among small, medium and large companies, and concluded that among 
the companies that introduced innovations to products or processes, the main source of information mentioned was the company itself, i.e., an internal source $(49.9 \%, 55.5 \%$ and $62.8 \%$, respectively for small, medium and large companies). As to external sources, clients are the most cited source $(33.9 \%, 36.3 \%$ and $41.4 \%)$, followed by suppliers $(20.3 \%, 20.3 \%$ and $16.7 \%)$, competitors $(8.7 \%, 10.8 \%$ and $12.1 \%)$ and participation in conferences $(8.3 \%$, $10 \%$ and $8.8 \%$ ). The role of universities as an information source for innovation comes in sixth, because only $2.5 \%$ of small companies, $3.3 \%$ of medium companies and $7.9 \%$ of large companies indicated this type of source, suggesting that the companies under study did not regard them as a very important source of information.

Studies on manufacturing industry suggest that the use of knowledge and information from external sources increase innovation performance of companies (see Laursen \& Salter, 2004). Although comparatively scarcer, studies focusing on services have succeeded in finding a significant relation between innovation outcomes and the use of external sources (Gallego et al., 2013b; Marin \& Bermejo, 2015). Marin and Bermejo (2015, p. 718) state that "the fact of service innovation being less reliant on internal R\&D efforts suggest that service companies can benefit from a strategy of innovation development based on the use of external sources." In an earlier and widely cited study, Tether (2005) found that while manufacturers are more likely to innovate through collaborations with universities and research institutes, service companies are more likely to make use of collaborations with customers and suppliers.

Accordingly, we present the following working hypothesis:

H3: The use of distinct sources of information for innovation (scientific, market, and others) is positively associated with innovation

H3a: The strength of the influence of the use of scientific/market/others related sources of information for innovation differs for the KIBS sector, compared to other service sectors

H3b: The strength of the influence of the use of the use of scientific/market/ others related sources of information for innovation differs for the services, compared to manufacturing industry

Innovation is regarded as the result of the interactive performance among various players and no longer as the mere isolated result of capabilities and internal operations of companies (Varis \& Littunen, 2010). The cooperation between companies and between these and other partners (such as clients, suppliers, universities and research institutes) have also been the focus of attention, because cooperation is key to success in the innovative process, due to the extreme complex environment and the demand for knowledge, which increases in quantity and specificity (Camacho \& Rodríguez, 2005).

Synergies can be developed through cooperative relationships and through access, sharing and complementarity of resources, capabilities, knowledge, experience and technology transfer (Gómez \& Murguía, 2010). When companies keep close links and mutually trust each other, there is less uncertainty and knowledge can be exchanged between partners, generating positive effects in terms of organizational learning and innovative performance (Hsueh, Lin, \& Li, 2010). The performance of other partners is also affected in that they can exchange knowledge and information (Vermeulen, De Jong, \& O'Shaughnessy, 2005). Moreover, the ongoing globalization of production and development processes has made cooperation with partners from other countries more relevant (Arvanitis \& Bolli, 2012).

According to Trigo and Vence (2012), most studies in the field of service innovation have pointed KIBS as the leading sub-sector not only in relation to innovation, but also to the cooperative activity. Such a performance would not only be 
the result of the high proportion of innovative companies, but mainly the consequence of the large number of innovative companies involved in most of the cooperation activities for innovation.

By relating the innovative activities in small Dutch service companies and the introduction of new products, Vermeulen el al. (2005) concluded that the use of external relations (for e.g., with suppliers and competitors) was most relevant, and that innovation in cooperation with other companies was only marginally significant. Hsueh et al. (2010) analyzed a set of software B2B (business-to-business) companies located in Taiwan and concluded that cooperation with suppliers and clients was positively and significantly related with the innovative performance of the companies, whereas cooperation with research institutes showed no significant relationship.

The impact of cooperation in nontechnological innovation (taking into consideration only those companies that have this type of innovation) was also analyzed by Schmidt and Rammer (2006), who concluded that companies that keep cooperation relationships with external partners are more likely to introduce organizational innovation, but nothing can be said in relation to innovation in marketing.

To ascertain the determinants and impact of national and international cooperation, and based on a comparative study of five European countries (Belgium, Germany, Norway, Portugal and Switzerland), Arvanitis and Bolli (2012) concluded that, overall, absorption capacity, yield spillovers and high suitability are determinants of both types, there being a stronger effect in international innovation; risk sharing, which is determinant only to international cooperation; and cost sharing, which was not determinant for any of the two types. In a more disaggregated analysis of determinants, the authors obtained significant differences between the manufacturing industry and services, and by country the results are more homogeneous in the case of international cooperation. In the specific case of Portugal, no relationship was established between the five determinants and national innovation (in fact,
Portugal is the only country showing this result), whereas in terms of international innovation yield spillovers and high suitability are positive and significant determinants.

Regarding the impact on the innovative performance of companies, Arvanitis and Bolli (2012) reveal that, in line with other research work, international cooperation shows a positive and highly significant effect (i.e., companies involved in innovation cooperation activities with foreign entities tend to be more innovative), whereas national cooperation is not statistically relevant. The manufacturing industry, services and Portugal show the same results (the impact of international cooperation is stronger in the manufacturing industry than in services).

Thus, based on existing literature, we believe that the participation in cooperation activities, in particular international cooperation, tends to have a positive effect on the innovation of companies because, according to Arvanitis and Bolli (2012), the motivation underlying international cooperation features the determinants associated with knowledge (e.g. use of technological synergies, access to specialized technology) because of the greater likelihood of finding, abroad, highly technologically skilled partners than within a single small country (Portugal). Moreover, and according to the same authors, these reasons seem to be more focused on finding a stronger innovative performance rather than on cost savings, which tends to benefit global companies' efficiency gains.

Below is our working hypothesis:

H4: The degree of openness to cooperation for innovation with foreign entities (companies, suppliers, clients, universities, etc.) is positively associated with innovation

H4a: The strength of the influence of the degree of openness to cooperation for innovation with foreign entities differs for the KIBS sector, compared to other service sectors 
H4b: The strength of the influence of the degree of openness to cooperation for innovation with foreign entities differs for the services, compared to manufacturing industry

\subsubsection{Control variables}

Other variables, for e.g., the size of the company, activity sector in which it operates, whether it is part of a group of multinational companies and its location in space enable the characterization of companies under study and are often used as control variables, since they are recognized, by literature, as being influential in the innovative performance of companies ( $\mathrm{He} \&$ Wong, 2009).

Company size can be considered an ambiguous determinant (Jong, Bruins, Dolfsma, \& Meijaard, 2003; Pires et al., 2008) because while the larger companies provide the necessary resources to promote innovation and are less exposed to risk of failure thereof, small companies have more flexible and less paper-sapping management structures that benefit innovation, so the effects whirl in opposite directions.

In the overall analysis of companies, as Pires et al. (2008) reason, size is positively relevant for all types of innovation studied (i.e., larger companies are more likely to introduce product and process innovations), but, as to the service companies, this is not the case - in fact, the impact is significantly greater than that observed for industry in process innovation only.

Schmidt and Rammer (2006) show that size, for all the companies studied, is positively and significantly related to both technological and non-technological innovation. He and Wong (2009) also agree that size is positively and significantly relevant for (product and process) innovation in the KIBS.

An important corporate feature is whether the companies under study are part of a multinational group. The insight of Pires et al. (2008) is that a company belonging to a multinational group would have a higher probability of being innovative, that is, multinationality would increase the efficiency of the innovative process due to, among other factors, greater learning and knowledge (of the various markets in which it operates), allowing multinational companies to capture and disseminate through their subsidiaries, but also because these subsidiaries are responsible for disseminating the innovative effects in their field of operation. In the data analysis of the overall companies, for a given size and level of $R \& D$ investment, the effect of a company participating in a multinational group is negative regarding product innovation, but positive in terms of process innovation. More specifically, for the services, belonging to a multinational group has a greater impact (than the one for the manufacturing industry) on product innovations, but a lower impact in the case of process innovations.

Finally, we can also point out as a relevant variable the impact of localization on innovation, in other words, the influence of regional innovation systems. Understanding the regional patterns of innovation helps explain, for e.g., the decision to locate a company and the tendency to spatial clustering, and it can also be an important instrument for promoting public regional development policies able to address the needs of certain regions and for making them more attractive to investment. Furthermore, it is important to assess the influence of the region and location in the innovative activities of companies (Broekel \& Brenner, 2011; Sternberg \& Arndt, 2001). According to Shearmur and Doloreux (2009), some regions or places are more innovative than others because of the association of institutional and cultural aspects, labor market characteristics and other intangible factors that positively impact on the innovative performance of companies. For Dautel and Walther (2014), urban fields feature a favorable environment for company innovation, especially for highly innovative companies: greater proximity, clustering of social players and greater interaction between them would result in a higher propensity to innovate. 


\section{Methodological considerations}

According to our "theoretical model", the determinants of innovation are: 1) the human capital as measured by the proportion of employees with undergraduate, Master's and $\mathrm{PhD}$ degrees; 2) the acquisition of knowledge expressed through external and continuous intramural $\mathrm{R} \& \mathrm{D}$, training for innovation and the purchase of machinery, equipment and software; 3) information sources for innovation, specifically the link with universities; 4) cooperation aimed at innovation, expressed by the cooperation with external and foreign entities (clients, suppliers, ...); and 5) control variables expressed by the size of the company, the element of belonging to a group of companies, multinationality, and location (region).

Since there are official statistics on the innovation activities of companies, collected through the Community Innovation Survey, we chose to use the latest available data from this survey, the CIS-2008, through a protocol signed with the Directorate General Statistics on Education and Science - DGEEC.

Thus, as dependent variables of our model we have, in addition to the various types of innovation that the CIS-2008 aims to measure (product, process, organizational and marketing innovation) and which will be directly implemented by the survey data, the binary variable Innovation, that takes the value 1 if the company belongs to the top $25 \%$ of most innovative companies in the sample. This dummy variable was created from an innovation index in which the companies were ordered from the most to the least innovative, based on the total sum of affirmative answers given to the total of 12 types of innovation measured (therefore, the scale of responses varies between 0 , when no innovation was made over the 2006-2008 period, and 12, if a company achieved all the various types of innovation in that three-year period).

With regard to the independent variables, human capital was determined from the point of view of schooling of human resources, namely the proportion of all employees working in each company surveyed with graduate, Master's and PhD degrees. To measure knowledge acquisition, we directly used the information collected in the survey, through the questions on the external and ongoing internal $\mathrm{R} \& \mathrm{D}$, training for innovation and the purchase of machinery, equipment and software. To measure the importance of scientific (Universities and other S\&TS, public and private R\&D institutes; Scientific journals and other publications), market (customers, suppliers, competitors), and Other (conferences, trade fairs, exhibitions; professional and industry associations) sources of information for innovation, we created dummy variables that take the value of 1 if the company indicates the source as being of "high" importance for its innovation activities.

To measure the intensity of cooperation for innovation with foreign entities, following the already cited work by Laursen and Salter (2004), ${ }^{6}$ we created an index of openness obtained from the responses of companies that claimed to have cooperated in innovation activities between 2006 and 2008. Therefore, each answer on partners of cooperation for innovation identified by the company was codified as a binary variable (excluding the answers related to other group companies - whether in Portugal or abroad - and to partners located in Portugal) and later added. Thus, the greater the number of foreign partners identified by a company, the greater its degree of "openness" to cooperation with such entities, which, in our opinion, will allow us to better list the companies participating in this type of activity and assume that those better placed in this index are among the top companies in terms of cooperation for innovation.

In the case of control variables, size is measured by the (logarithm of the) number of employees in the company in 2008, the information whether the companies belong to a group is collected directly from the survey and multinationality is measured through a variable that gathers all the companies that, belonging to a 
group of companies, have their registered office or other group companies outside Portugal. To assess the presence or absence of regional innovation patterns, we created dummy variables for each NUTS II region.

The Community Innovation Survey (CIS) is the main tool for collecting information on innovation in European companies, mandatory in all European Union Members States, according to Eurostat methodological guidelines and the conceptual framework established in the Oslo Manual. The CIS-2008 covers the period 2006-2008.

As in other studies aiming to examine the determinants of innovation (e.g. Moreira et al., 2012; Pires et al., 2008; Varis \& Littunen, 2010), this study uses a multivariate econometric model, more specifically, a logistic regression. Actually, this estimation procedure allows us to determine how the various determinants mentioned above impact on the likelihood of a company being innovative.

Our units of analysis are the companies located in Portugal. As described in our "theoretical model”, the innovative performance of a company depends on five major groups of determinants (the independent variables), including human capital, acquisition of knowledge, information sources for innovation, cooperation for innovation and other control variables. For the dependent variable, "innovative company" is a dummy variable that takes the value of 1 when the company is (top) innovative and 0 when it is not.

To obtain a more direct interpretation of the logistic coefficients, the original equation is rewritten in terms of probabilities of the event taking place (probability ratio between the occurrence and non-occurrence of the event), in order to obtain the following logarithmic model:

$$
\begin{aligned}
& \log \left(\frac{\text { Prob(innovative_company })}{\text { Prob(non innovative_company) })}\right)= \\
& =\beta_{0}+\underbrace{\beta_{1} \text { Undergraduate degree }+\beta_{2} \text { Masters }+\beta_{3} P h D}_{\text {humancapital }}+ \\
& +\underbrace{\beta_{4} R D_{\text {continuous }}+\beta_{5} R D_{\text {external }}+\beta_{6} \text { Training_inov }+\beta_{7} \text { Purchase mach_equip }}_{\text {knowledge acquisition }}+ \\
& +\underbrace{\beta_{8} \text { Scientific }+\beta_{9} \text { Market }+\beta_{10} \text { Others }}_{\text {information sources }}+\underbrace{\beta_{11} I_{-} \text {coop_foreign }+}_{\text {cooperation }} \\
& +\underbrace{\beta_{12} \text { Size }}_{\text {size }}+\underbrace{\beta_{13} \text { Group }}_{\text {group }}+\underbrace{\beta_{14} \text { Multinational }}_{\text {multinationality }}+\underbrace{\beta_{15} \text { NUTS II }}_{\text {region }}+\varepsilon_{i}
\end{aligned}
$$

The logistic coefficient can be interpreted as a variation of the logarithmic probability associated with a unit variation in the dependent variable. Thus, the value of $e$ raised to $b_{i}$ is the factor by which the odds change when the independent variable increases one unit. If $b_{\mathrm{i}}$ is positive, the factor will be greater than 1, which means that the odds have increased; if $b_{\mathrm{i}}$ is negative, the factor will be less than 1 , which means that the odds have decreased; finally, when $b_{\mathrm{i}}$ is 0 , the factor equals 1 , leaving the odds unchanged. 


\section{Empirical results}

The models estimated (see Table 1) reveal a reasonable goodness of fit: the Nagelkerke's $\mathrm{R}^{2}$ is between 0.204 (Model C-Manufacturing) and 0.256 (Model B - KIBS) indicates that the models are good but not great. The -2 LL is a likelihood ratio represents the unexplained variance in the outcome variable - therefore, the smaller the value, the better the fit: the -2 LL obtained in each model in Table 1 is substantially lower than that given for the corresponding null model. Additionally, correct classification of 70\%-77\% evidence that the models are satisfactory. The Hosmer and Lemeshow Test, the preferred/widely used test of goodness-of-fit (Xie, Pendergast, \& Clarke, 2008), indicate that models fit is good with p-values above 0.10 (i.e., our models predict values not significantly different from what we observed).

Regarding the first hypothesis (H1: Human capital is positively and significantly associated with innovation), estimations reflect that service companies with a greater proportion of human resources holding an undergraduate degree $\left(1^{\text {st }}\right.$ cycle) are, on average, more innovative (i.e., they fall within the top 25 percentile of innovation) than their counterparts whose employees have lower levels of academic qualification (in percentage terms). However, service companies with a greater proportion of $\mathrm{PhDs}$ tend to be less prone to innovation than those with a proportion of human resources whose education level is lower than the undergraduate degree (see Table 1). In short, $H 1$ is partially verified.

Additionally, although human capital levels have relatively similar impact for services and KIBS, they distinctly impact on manufacturing companies. For these latter, the percentage of both undergraduate and $\mathrm{PhD}$ workers in total fail to emerge as significantly relevant for the innovative performance of manufacturing companies, whereas master endowed workers significantly foster innovation. Thus, HIa is corroborated whereas $H 2 b$ is supported by the data.

\section{Table 1}

Determinants of innovative performance of Portuguese service companies, 2006-2008 [dependent variable: the company belongs to the upper quartile of most innovative companies]

\begin{tabular}{|c|c|c|c|c|c|}
\hline & & & Services & KIBS & Manufacturing \\
\hline & & & Model A & Model B & Model C \\
\hline \multirow{7}{*}{ 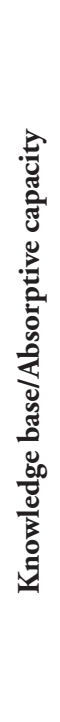 } & \multirow{3}{*}{ Human capital } & Proportion of employees with $\mathbf{1}^{\text {st }}$ cycle (2008) & $0,209^{*}$ & $0,136^{* *}$ & 0,078 \\
\hline & & $\begin{array}{l}\text { Proportion of employees with } 2^{\text {nd }} \text { cycle (master) } \\
\text { (2008) }\end{array}$ & $-1,057$ & 1,157 & $9,163^{* *}$ \\
\hline & & $\begin{array}{l}\text { Proportion of employees with } 3^{\text {rd }} \text { cycle (PhD) } \\
(2008)\end{array}$ & $-7,310^{* *}$ & $-9,516^{* * *}$ & 3,835 \\
\hline & \multirow{4}{*}{ Knowledge } & $\begin{array}{l}\text { Continuous intramural R\&D }(2006-2008) \\
{[\text { Dummy variable }(1=\text { if company carried out }} \\
\text { this activity; } 0=\text { no) }\end{array}$ & $0,599^{* * *}$ & $0,761^{* * *}$ & $0,545^{* * *}$ \\
\hline & & $\begin{array}{l}\text { External R\&D acquisition ( } 2006- \\
\text { 2008) [Dummy variable }(1=\text { if company } \\
\text { subcontracted/acquired external } R \& D ; 0=\text { no })]\end{array}$ & $0,590^{* * *}$ & $0,681^{* * *}$ & $0,616^{* * *}$ \\
\hline & & $\begin{array}{l}\text { Training activities for innovation }(2006-2008) \\
{[\text { Dummy variable }(1=\text { if company carried out }} \\
\text { this activity; } 0=\text { no) }]\end{array}$ & $0,765^{* * *}$ & $0,599^{* * *}$ & $0,800^{* * *}$ \\
\hline & & $\begin{array}{l}\text { Acquisition of machinery, equipment and } \\
\text { software }(2006-2008)[\text { Dummy variable }(1=\text { if } \\
\text { company carried out this activity; } 0=\text { no) }]\end{array}$ & $0,605^{* * *}$ & $0,652^{* *}$ & $0,570^{* * *}$ \\
\hline
\end{tabular}




\begin{tabular}{|c|c|c|c|c|c|}
\hline & & & Services & KIBS & Manufacturing \\
\hline & & & Model A & Model B & Model C \\
\hline \multirow{4}{*}{ 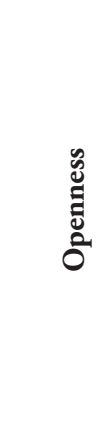 } & \multirow{3}{*}{$\begin{array}{l}\text { Relevance of the source } \\
\text { of information for } \\
\text { innovation (dummy } \\
\text { variable }=1 \text { if the company } \\
\text { consider the referred } \\
\text { entities an very important } \\
\text { source of information) }\end{array}$} & $\begin{array}{l}\text { Scientific related sources (Universities and } \\
\text { other S\&TS, public and private R\&D institutes; } \\
\text { Scientific journals and other publications) }\end{array}$ & $0,480^{*}$ & $1,147^{*}$ & $-0,409$ \\
\hline & & $\begin{array}{l}\text { Market related sources (customers, suppliers, } \\
\text { competitors) }\end{array}$ & $0,856^{* * *}$ & $-0,110$ & $0,351^{*}$ \\
\hline & & $\begin{array}{l}\text { Other sources (conferences, trade fairs, } \\
\text { exhibitions; professional and industry } \\
\text { associations) }\end{array}$ & 0,062 & 0,021 & $1,109^{* * *}$ \\
\hline & Cooperation & $\begin{array}{l}\text { Company's openness to cooperation for } \\
\text { innovation with foreign entities }(\ln )\end{array}$ & $0,531^{* * *}$ & $0,508^{* *}$ & $0,546^{* * *}$ \\
\hline \multirow{3}{*}{\multicolumn{2}{|c|}{ Company's traits }} & Size (total number of employees in $2008, \ln$ ) & 0,063 & 0,084 & $-0,059$ \\
\hline & & $\begin{array}{l}\text { Group (dummy variable }=1 \text { if the company } \\
\text { belongs to a Group of companies) }\end{array}$ & $-0,023$ & $-0,620^{* *}$ & $-0,443^{* * *}$ \\
\hline & & $\begin{array}{l}\text { Multinational (dummy variable }=1 \text { if the } \\
\text { company's or group's headquarters is located } \\
\text { outside Portugal) }\end{array}$ & 0,299 & $1,090^{* * *}$ & 0,325 \\
\hline \multirow{5}{*}{\multicolumn{2}{|c|}{$\begin{array}{l}\text { NUTs II Region } \\
\text { [default: Lisbon] }\end{array}$}} & North & $0,247^{*}$ & 0,161 & 0,239 \\
\hline & & Centre & $-0,091$ & 0,402 & 0,138 \\
\hline & & Alentejo & $-0,125$ & $-0,202$ & 0,175 \\
\hline & & Algarve & 0,061 & 0,408 & $-0,192$ \\
\hline & & Islands & $-0,230$ & $-0,021$ & $-0,010$ \\
\hline \multicolumn{3}{|c|}{ Constant } & $-2,403$ & $-2,305$ & $-2,505$ \\
\hline \multicolumn{3}{|l|}{$\mathrm{N}$} & 1489 & 434 & 2090 \\
\hline \multicolumn{3}{|c|}{ Upper quartile of innovators } & 588 & 180 & 549 \\
\hline \multicolumn{2}{|l|}{ Other } & & 901 & 254 & 1541 \\
\hline \multirow{5}{*}{\multicolumn{2}{|c|}{ Suitability }} & $-2 \mathrm{LL}$ & 1708.600 & 497,320 & 2092,459 \\
\hline & & Cox e Snell R ${ }^{2}$ & 0,177 & 0,190 & 0,140 \\
\hline & & Nagelkerke $\mathrm{R}^{2}$ & 0,239 & 0,256 & 0,204 \\
\hline & & Hosmer and Lameshow Test (p-value) & $\begin{array}{l}12,813 \\
(0,118)\end{array}$ & $\begin{array}{l}8,767 \\
(0,362)\end{array}$ & $\begin{array}{l}7,241 \\
(0,511)\end{array}$ \\
\hline & & $\%$ correto & 69,8 & 70,2 & 76,6 \\
\hline
\end{tabular}

Knowledge-related variables emerge as very significantly related to companies' innovation performance, regardless the sector considered. Thus, H2 is strongly supported by our data. Moreover, and based on the size of the estimates, external and continuous R\&D efforts seem to be much more important for KIBS than for the generality of Services or for Manufacturing companies. For the latter, training for innovation is particularly (more) crucial. Thus, $\mathrm{H} 2 a$ and $H 2 b$ are supported by our data.

Estimates associated with the sources of information for innovation support the view that the importance attributed to external sources matter for innovation performance. Thus, H3 is verified. In the service sector and, to a larger extent, in KIBS, the companies that use scientific related sources (e.g., universities and other SC\&T entities) emerge as significantly more innovative than other companies in the same sector. On average, and controlling for all the other factors, a KIBS company that attribute high importance to scientific related sources presents an odds ratio of innovation three times higher than their remaining counterparts. Interestingly, this is not true for manufacturing companies. Market related 
sources (customers, suppliers, competitors) are particularly relevant for service and, in a lesser extent, for manufacturing companies. This means that $H 3 a$ is partially confirmed, whereas no sufficient evidence exists to verify $H 3 b$.

Overall, companies that reveal a greater degree of openness to cooperation for innovation with foreign entities, whether competitors, suppliers, clients, universities or others, appear to be more innovative (i.e., $\mathrm{H} 4$ is corroborated). No noticeable differences exist regarding the size and the significance of the estimates of this variable for Services and Manufacturing, but for KIBS, the size and significance (Model 2B) of the corresponding estimates are lower. In short, $\mathrm{H} 4 \mathrm{a}$ is supported, whereas $H 4 b$ cannot be confirmed.

Regarding the control variables (region, multinationality, belonging to a group of companies and size of the company), in general, the results show that in the case of KIBS multinationals (i.e., which have units or registered office of the group located outside Portugal), they are, on average, more innovative than their remaining counterparts. There is no (or very weak) evidence of regional patterns of innovation in the sample under study.

\section{Discussion and conclusions}

The scope of this article was to analyze the determinants of innovation in Portugal for the service and KIBS companies as compared to manufacturing companies.

Regarding human capital, we were able to confirm that it is an important determinant of innovation. Our results are partially in line with existing works. In fact, in the results of Pires et al. (2008), who also worked with CIS data for Portugal (although earlier data), the level of schooling emerges as positively and significantly related with (process) innovation. The same applies to data presented by Schmidt and Rammer (2006), where process and product innovation showed a positive and significant relationship with the level of schooling of employees.

In the present study, human capital appears as positively associated with innovation in service and KIBS companies, but only up to the $1^{\text {st }}$ cycle level (undergraduates). Service and (in larger extent) KIBS companies with a higher percentage of PhDs are, in our sample, significantly less innovative. This result is quite surprising, since one would expect that the rise of a more knowledge-based economy would render $\mathrm{PhD}$ individuals, who are trained to conduct research, critical elements in the creation, commercialization and diffusion of innovations (Garcia-Quevedo et al., 2012; Herrera \& Nieto, 2015). Our results strongly contradict this idea, at the least for Services and KIBS (in the Manufacturing case nothing can be concluded in this regard). Such results might be explained by over-qualification and/or mismatched qualification (Kulkarni, LengnickHall, \& Martinez, 2015) which harmfully impact innovation (Agut, Peiró, \& Grau, 2009).

In terms of services in general, and KIBS in particular, the tendency of these companies to innovate is significantly reduced if the company has a high proportion of employees with a $\mathrm{PhD}$ degree, which is surprising when we are talking about knowledge-intensive services. It would also seem to be counter intuitive that, in general, a company tends to be much more innovative if the average level of schooling of its employees is higher, i.e., if its human capital is greater.

Our results emphasize the crucial role played by knowledge-sourcing activities for the innovation process of Portuguese service companies. It is important to highlight the positive and significant impact of both external and continuous in-house $R \& D$ in service companies, especially in companies belonging to KIBS (where the impact is even greater). Contrary to the arguments in literature that the innovation process in these companies is non-systematized, ad hoc (Sundbo, 2000) and take place as part of the daily work (Crevani et al., 2011), results show that companies that, in this sector, effectively and continuously invest in research and development activities are more innovative. This is perfectly consistent with the fact that these activities are not often formally organized, i.e., linked to specific 
departments, namely the R\&D department (Crevani et al., 2011; Organization for Economic Co-operation and Development [OECD], 2005b; Sundbo, 2000).

The results are, therefore, in line with those found by Camacho and Rodríguez (2005) for the Spanish service companies. Specifically, the authors found that the most innovative sectors in services are characterized by having, in their innovation process, investments made in internal Research and Development activities, citing the example of the software sector (which is a knowledge-intensive service, i.e., a KIBS).

As regards the information sources for innovation, more specifically the importance of scientific related sources, most notably, universities, in this field, we found that only $22.9 \%$ of all companies surveyed mentioned having used universities and other entities of the Scientific and Technological System (SC\&T) as an information source, and only $3.2 \%$ indicated it as an information source of "high" importance for the company's innovation activities, which suggests a weak relationship between universities and companies, already documented for the Portuguese case (Teixeira \& Costa, 2012). Interestingly, service companies, in general, and (to a larger extent) KIBS companies, in particular, that use scientific sources of information for their innovation activities, and feel that they are a "highly" important source in their innovative process, on average, and all else being equal, tend to be more innovative than their counterparts. Customers, suppliers and competitors are very relevant sources for service companies, which is in line with earlier empirical studies (see Chang et al., 2012). In contrast with Love, Roper and Bryson (2011) who underlined the relevance of professional associations in the exploitation stage of the innovation value chain, we failed to encounter statistical evidence to support the relevance of such source for services and KIBS innovation performance. For manufacturing companies, the importance of Other sources (e.g., conferences, trade fairs, professional associations) is paramount.
Cooperation for innovation with foreign entities emerges as positively and strongly related to the innovative performance of service companies, including KIBS. Such results corroborate those presented by Arvanitis and Bolli (2012). Bearing in mind these results, we can state that developing activities in cooperation with foreign partners strongly determines the innovative performance of service companies located in Portugal.

There is a possible mismatch between the national higher education system and Portuguese businesses, which shows in the results on the impact of human capital and information sources for innovation. It would be important to determine in future research the reasons behind this mismatch. However, we can conjecture, for e.g., that there is a possible inadequacy of courses offered by Portuguese universities (especially at the higher levels - PhD) and the demand/need of companies, since hiring more qualified human resources is not reflected in a better innovative performance of companies, not even in the knowledge-intensive ones (with the exception of the manufacturing industry in terms of Masters' degrees). This mismatch between offer/demand can also be the result of the weak relationship between universities and other SC\&T entities and companies (López et al., 2015). Thus, caution is needed in the promotion of public financed programs for encouraging the professional insertion of $\mathrm{PhDs}$ in companies. ${ }^{7}$ If thoughtlessly managed, these programs might induce lower innovation performance in Services and KIBS.

We believe that these results may reveal a weakness in the relationship between those responsible for organizing the Portuguese National System of Innovation, specifically between companies and the education and research system, corroborating the argument put forward by Fontes and Coombs (2001), according to which Portugal is a country of "intermediate development" because it has problems/flaws in communication between public and private stakeholders in its national innovation system.

In our opinion, there has to be an effort to bridge the gap between companies and 
universities, in order to increase the participation of universities day-to-day, in the more practical aspects of innovation, experienced by companies and seldom explored by researchers; and, on the other hand, to provide companies with more technical support in order to encourage and optimize investments in innovation. That is, we must invest in improving and strengthening this relationship for a win-win situation, by collaborating and taking advantage of synergies - and, in the end, the national economic development will be the winner.

Conversely, despite Portuguese companies barely recognizing the value added of scientific sources, most notably universities, for their innovation performance, they are "open" to international cooperation, making this type of innovation a very important determinant in the innovative process. The reasons for this may be related with the characteristics of the Portuguese economy, small and open to the outside, part of a common market, which would facilitate and motivate companies to seek partnerships abroad.

Another aspect to take into consideration is the relationship that can be established between the results obtained for human capital and for the activities of acquiring knowledge. Thus, although the results obtained for the human capital variables are not straightforward, there being even significantly negative impacts on the tendency to innovate by companies belonging to some sectors, this does not mean that they are not concerned with the level of knowledge inside the companies, which corroborates the results of the activities of knowledge acquisition, which turned out to be a cross-cutting determinant. The results of training for the innovation variable, which is always positive and strongly significant in any of the models estimated, whatever the sectors, taxonomies or region, is expressive.

The present study contributes to the empirical literature in the field by showing that even in a relatively laggard country as Portugal in terms of technological performance, service (in particular KIBS) companies that are more open to establish linkages with scientific sources (e.g., universities and other entities of the S\&TS), that invest in knowledge sourcing activities such as external and continuous intramural $R \& D$, training activities for innovation, and acquisition of machinery, equipment and software are much more innovative at the various levels (product, process, organizational and marketing).

Our general results are in harmony with the proposed theoretical framework - the services regime - and with Chang et al. (2012), whose findings established services as systems with varied sources of innovation and manifold innovation paths.

An interesting path for further research in this field would be to assess the extent to which the importance of the distinct determinants of innovation performance varied according to the innovation type.

\section{References}

Aboal, D., Bravo-Ortega, C., \& Cresp, G. (2015). Innovation in the services sector. Emerging Markets Finance \& Trade, 51(3), 537-539.

Agut, S., Peiró, J. M., \& Grau, R. (2009). The effect of overeducation on job content innovation and career-enhancing strategies among young Spanish employees. Journal of Career Development, 36(2), 159-182.

Álvarez, R., Bravo-Ortega, C., \& Zahler, A. (2015). Innovation and productivity in services: Evidence from Chile. Emerging Markets Finance and Trade, 51(3), 593-611.

Añón Higón, D. (2016). In-house versus external basic research and first-to-market innovations. Research Policy, 45(4), 816-829.

Arundel, A., Kanerva, M., Cruysen A.V., \& Hollanders, H. (2007). Innovation statistics for the European service sector [Report Inno Metrics]. UNU-MERIT Maastricht University, Maastricht, The Netherlands. Retrieved from http:// www.seeproject.org/images/Innovation $\% 20$ Statistics\%20for\%20 the \%20European \% 20 Service\%20Sector.pdf 
Arvanitis, S., \& Bolli, T. (2012). A comparison of national and international innovation cooperation in five European countries. Review of Industrial Organization, 43(3), 163-191.

Barras, R. (1986). Towards a theory of innovation in services. Research Policy, 15(4), 161-173.

Barroca, A., Meireles, G. \& Neto, C. (2015). A empregabilidade dos doutorados nas empresas portuguesas. Porto: Advancis Business Services. Retrieved from http//www. empregabilidadedoutorados.com/

Battisti, G., Gallego, J., Rubalcaba, L. \& Windrum, P. (2015). Open innovation in services: Knowledge sources, intellectual property rights and internationalization. Economics of Innovation and New Technology, 24(3), 223-247.

Becker, G. S. (1983). Human capital: A theoretical and empirical analysis with special reference to education. Chicago, IL: University of Chicago Press.

Broekel, T., \& Brenner, T. (2011). Regional factors and innovativeness: An empirical analysis of four German industries. The Annals of Regional Science, 47(1), 169-194.

Bryson, J., \& Monnoyer, M. (2004). Understanding the relationship between services and innovation: The RESER review of the European service literature on innovation. The Service Industries Journal, 24(1), 205-222.

Cáceres, R., \& Guzmán, J. (2014). Seeking an innovation structure common to both manufacturing and services. Service Business, 9(3), 361-379.

Camacho, J., \& Rodríguez, M. (2005). How innovative are services? An empirical analysis for Spain. The Service Industries Journal, 25(2), 253-271.

Carlborg, P., Kindström, D., \& Kowalkowski, C. (2014). The evolution of service innovation research: A critical review and synthesis. Service Industries Journal, 34(5), 373-398.
Carvalho, L., Costa, T., \& Caiado, J. (2013). Determinants of innovation in a small open economy: A multidimensional perspective. Journal of Business Economics and Management, 14(3), 583-600.

Castellacci, F. (2010). The internationalization of firms in the service industries: Channels, determinants and sectoral patterns. Technological Forecasting and Social Change, 77(3), 500-513.

Castro, L. M., Montoro-Sanchez, A., \& Criado, M. O. (2011). Innovation in services industries: Current and future trends. The Service Industries Journal, 31(1), 7-20.

Chang, Y.-C., Linton, J. D., \& Chen, M.-N. (2012). Service regime: An empirical analysis of innovation patterns in service firms. Technological Forecasting \& Social Change, 79(9), 1569-1582

Chesbrough, H. (2003). Open innovation: The new imperative for creating and profiting from technology. Boston, MA: Harvard Business School Press.

Cohen, W., \& Levinthal, D. A. (1990). Absorptive capacity: A new perspective on learning and Innovation. Administrative Science Quarterly, 35(1), 128-152.

Coombs, R., \& Miles, I., (2000). Innovation, measurement and services, the new problematic. In J. S. Metcalfe \& I. Miles (Eds.), Innovation systems in the service economy: Measurement and case study analysis (pp. 85-103). Boston: Kluwer Academic Publishers.

Crevani, L., Palm, K., \& Schilling, A. (2011). Innovation management in service firms: A research agenda. Service Business, 5(2), 177-193.

Crook, T. R., Todd, S. Y., Combs, J. G., \& Woehr, D. J. (2011). Does human capital matter? A meta-analysis of the relationship between human capital and firm performance. Journal of Applied Psychology, 96(3), 443-456. 
Czarnitzki, D., \& Spielkamp, A. (2003). Business services in Germany: Bridges for innovation. The Service Industries Journal, 23(2), 1-30.

Dautel, V., \& Walther, O. (2014). The geography of innovation in the Luxembourg metropolitan region, an intra-regional approach. Papers in Regional Science, 93(4), 703-725.

De Fuentes, C., Dutrenit, G., Santiago, F., \& Gras, N. (2015). Determinants of innovation and productivity in the service sector in Mexico. Emerging Markets Finance and Trade, 51(3), 578-592.

Djellal, F., \& Gallouj, F. (2001). Patterns of innovation organisation in service firms: Postal survey results and theoretical models. Science and Public Policy, 28(1), 57-67.

Djellal, F., Gallouj, F., \& Miles, I. (2013). Two decades of research on innovation in services: Which place for public services? Structural Change and Economic Dynamics, 27, 98-117.

Drejer, I. (2004). Identifying innovation in surveys of services: A Schumpeterian perspective. Research Policy, 33(3), 551-562.

Droege, H., Hildebrand, D., \& Forcada, M. (2009). Innovation in services: Present findings, and future pathways. Journal of Service Management, 2O(2), 131-155.

Evangelista, R., \& Vezzani, A. (2010). The economic impact of technological and organizational innovations: A firm-level analysis. Research Policy, 39(10), 1253-1263.

Fontes, M., \& Coombs, R. (2001). Contribution of new technology-based firms to the strengthening of technological capabilities in intermediate economies. Research Policy 30(1), 79-97.

Forsman, H. (2011). Innovation capacity and innovation development in small enterprises: A comparison between the manufacturing and service sectors. Research Policy, 4O(5), 739-750.
Freel, M. (2005). Patterns of innovation and skills in small firms. Technovation, 25(2), 123-134.

Gallego, J. M., Gutiérrez, L. H., \& Taborda, R. (2015). Innovation and productivity in the Colombian service and manufacturing industries. Emerging Markets Finance and Trade, 51(3), 612-634.

Gallego, J. M., Rubalcaba, L., \& Hipp, C. (2013a). Services and organisational innovation: The right mix for value creation. Management Decision, 51(6), 1117-1134.

Gallego, J. M., Rubalcaba, L., \& Suarez, C. (2013b). Knowledge for innovation in Europe: The role of external knowledge on firms' cooperation strategies. Journal of Business Research, 66(10), 2034-2041.

Gallouj, F. (2002a). Innovation in services and the attendant old and new myths. Journal of SocioEconomics 31(2), 137-154.

Gallouj, F. (2002b). Innovation in the service economy: The new wealth of nations. Cheltenham: Edward Elgar.

Gallouj, F., \& Savona, M. (2009). Innovation in services: A review of the debate and a research agenda. Journal of Evolutionary Economics, 19(2), 149-172.

Gallouj, F., Weber, K. M., Stare, M., \& Rubalcaba, L. (2015). The futures of the service economy in Europe: A foresight analysis. Technological Forecasting and Social Change, 94, 80-96.

Gallouj, F., \& Weinstein, O. (1997). Innovation in services. Research Policy, 26(4-5), 537-556.

García-Quevedo, J., Mas-Verdu, F., \& PoloOtero, J. (2012). Which firms want PhDs? An analysis of the determinants of the demand. Higher Education, 63(5), 607-620.

García-Quevedo, J., Pellegrino, G., \& Vivarelli, M. (2014). R\&D drivers and age: Are young firms different?. Research Policy, 43(9), 1544-1556. 
Gomes, C., Kruglianskas, I., \& Scherer, F. (2011). Gestão das fontes externas de informação: Uma análise dos fatores que influenciam o desempenho inovador. Gestão \& Produção, 18(4), 897-910.

Gómez, J., \& Murguia, C. (2010). Vínculos de cooperación como fuente de información para la innovación. Cuadernos de Administración, 23(41), 61-79.

He, Z. L., Wong, P. K. (2009), Knowledge interaction with manufacturing clients and innovation of knowledge-intensive business services firms. Innovation, Management, Policy and Practice, 11(3), 264-278.

Herrera, L., \& Nieto, M. (2015). The determinants of firms' $\mathrm{PhD}$ recruitment to undertake R\&D activities. European Management Journal, 33(2), 132-142.

Hertog, P. den, Aa, W. van der, \& Jong. M. (2010). Capabilities for managing service innovation: Towards a conceptual framework. Journal of Service Management, 21(4), 490-514.

Hsueh, J., Lin, N., \& Li, H. (2010). The effects of network embeddedness on service innovation performance. The Service Industries Journal, 3O(10), 1723-1736.

Janeiro, P., Proença, I., \& Gonçalves, V. C. (2013). Open innovation: Factors explaining universities as service firm innovation sources. Journal of Business Research, 66(10), 2017-2023.

Jong, J. P. J., Bruins, A., Dolfsma, W., \& Meijaard, J. (2003). Innovation in service firms explored: What, how and why? [Strategic Study B2002205], EIM Business \& Policy Research, Zoetermeer, Netherlands.

Kulkarni, M., Lengnick-Hall, M. L., \& Martinez, P.G. (2015). Overqualification, mismatched qualification, and hiring decisions: Perceptions of employers. Personnel Review, 44(4), 529- 549.

Laursen, K., \& Salter, A. (2004). Searching high and low: What types of firms use universities as a source of innovation? Research Policy, 33(8), 1201-1215.

Lazzarotti, V., Manzini, R., Nosella, A., \& Pellegrini, L. (2016). Collaborations with scientific partners: The mediating role of the social context in fostering innovation performance. Creativity and Innovation Management, 25(1), 142-156.

Leiponen, A. (2012). The benefits of R\&D and breadth in innovation strategies: A comparison of finnish service and manufacturing firms. Industrial and Corporate Change, 21(5), 1255-1281.

López, A., \& Ramos, D. (2015). Innovation in services: The case of rural tourism in Argentina. Emerging Markets Finance \& Trade, 51(3), 635646.

López, S. F, Astray, B. P., Pazos, D. R., \& Calvo, N. (2015). Are firms interested in collaborating with universities? An open-innovation perspective in countries of the South West European Space. Service Business, 9(4), 637-662.

Love, J. H., Roper, S., \& Bryson, J. R. (2011). Openness, knowledge, innovation and growth in UK business services. Research Policy, 4O(10), 1438-1452.

Máñez, J. A., Rochina-Barrachina, M. E., SanchisLlopis, A., \& Sanchis-Llopis, J. A. (2015). The determinants of R\&D persistence in SMEs. Small Business Economics, 44(3), 505-528.

Marin, H. J. L., \& Bermejo, L.R. (2015). External sources for innovation in public organisations. The Service Industries Journal, 35(13), 710-727.

McGuirk, H., Lenihan, H. \& Hart, M. (2015). Measuring the impact of innovative human capital on small firms' propensity to innovate. Research Policy, 44(4), 965-976.

Moreira, J., Silva, M. J., Simōes, J., \& Sousa, G. (2012). Drivers of marketing innovation in Portuguese firms. The Amfiteatru Economic Journal, 14(31), 195-206. 
Nardelli, G. (2015). The interactions between information and communication technologies and innovation in services: A conceptual typology. International Journal of Information Systems in the Service Sector, 7(3), 15-39.

Organisation for Economic Co-operation and Development (2005a). Oslo Manual: Guidelines for collecting and interpreting innovation data (3rd ed.). France. Retrieved from http//ec.europa.eu/ eurostat/documents/3859598/5889925/OSLOEN.PDF

Organisation for Economic Co-operation and Development (2005b). Promoting innovation in services [Working party on innovation and technology policy, DSTI/STP/TIP(2004)4/ Final]. OECD Publications, Paris, France. Retrieved from http.//www.oecd.org/sti/ inno/35509923.pdf

Pires, C., Sarkar, S., \& Carvalho, L. (2008). Innovation in services: how different from manufacturing? The Service Industries Journal, 28(10), 1339-1356.

Robinson, S., \& Stubberud, H. (2011). Sources of information and cooperation for innovation in Norway. Journal of International Business Research, 10(2), 91-102.

Rubalcaba, L., Gago, D., \& Gallego, J. (2010). On the differences between goods and services innovation. Journal of Innovation Economics, 1(5), $17-40$.

Schmidt, T., \& Rammer, C. (2006). The determinants and effects of technological and non-technological innovations: Evidence from the German CIS IV. Retrieved from http//www. oecd.org/sti/inno/37450197.pdf

Schneider, L., Gunther, J., \& Brandenbury, B. (2010). Innovation and skills from a sectoral perspective: A linked employer-employee analysis. Economics of Innovation and New Technology, 19(2), 185-202.
Shearmur, R., \& Doloreux, D. (2009). Place, space and distance: Towards a geography of knowledge-intensive business services innovation. Industry and Innovation, 16(1), 79-102.

Sirilli, G., \& Evangelista, R. (1998). Technological innovation in services and manufacturing: Results from Italian surveys. Research Policy, 27(9), 881899.

Sternberg, R., \& Arndt, O. (2001). The firm or the region: What determines the innovation behavior of European firms? Economic Geography, 77(4), 364-382.

Sundbo, J. (2000). Organization and innovation strategy in services. In M. Boden \& I. Miles (Eds.), Services and the Knowledge-Based Economy (pp. 109-128). New York: Continuum.

Tacsir, E. (2011). Innovation in services: The hard case for Latin America and the Caribbean [Discussion paper, n. IDB-DP-203]. InterAmerican Development Bank, Washington, DC. Retrieved from https.//publications.iadb.org/ bitstream/handle/11319/5081/IDBDP203\%20 Innovation $\% 20$ in $\% 20$ Services.pdf?sequence $=1$

Teixeira, A. A. C., \& Mota, L. (2012). A bibliometric portrait of the evolution, scientific roots and influence of the literature on universityindustry links. Scientometrics, 93(3), 719-743.

Teixeira, A. A. C., \& Tavares-Lehmann, A. T. (2014). Human capital intensity in technologybased firms located in Portugal: Does foreign ownership matter? Research Policy, 43(4), 737748.

Tether, B. S. (2005). Do services innovate (differently)? Insights from the European innobarometer survey. Industry and Innovation, 12(2), 153-184.

Tether, B. S., \& Howells, J. (2007). Changing understanding of innovation in services [DTI Occasional Paper, n. 9]. Innovation in Services, Department of Trade and Industry, Manchester. 
Tether, B. S., \& Tajar, A. (2008). Beyond industry-university links: Sourcing knowledge for innovation from consultants, private research organisations and the public sciencebase. Research Policy, 37(6-7), 1079-1095.

Toivonen, M., \& Tuominen, T. (2009). Emergence of innovations in services. The Service Industries Journal, 29(7), 887-902.

Trigo, A., \& Vence, X. (2012). Scope and patterns of innovation cooperation in Spanish service enterprises. Research Policy, 41(3), 602-613.

Un, C., \& Montoro-Sanchez, A. (2010). Public funding for product, process and organizational innovation in service industries. The Service Industries Journal, 30(1), 133-147.

Uppenberg, K., \& Strauss, H. (2010). Innovation and Productivity Growth in the EU Services Sector. European Investment Bank. Retrieved from http://www.eib.org/attachments/efs/efs_ innovation_and_productivity_en.pdf

Varis, M., \& Littunen, H. (2010). Types of innovation, sources of information and performance in entrepreneurial SMEs. European Journal of Innovation Management, 13(2), 128154.

Vergori, A. S. (2014). Measuring innovation in services: The role of surveys. The Service Industries Journal, 34(2), 145-161.

Vermeulen, P. A. M., De Jong, J. P. J., \& O'Shaughnessy, K. C. (2005). Identifying key determinants for new product introductions and firms perfomance in small service firms. The Service Industries Journal, 25(5), 625-640.

Vinding, A. L. (2006). Absorptive capacity and innovative performance: A human capital approach. Economics of Innovation and New Technology, 15(4-5), 507-517.

West, J., \& Bogers, M. (2014). Leveraging external sources of innovation: a review of research on open innovation. Journal of Product Innovation and Management, 31(4), 814-831.

Xie, X.-J., Pendergast, J., \& Clarke, W. (2008). Increasing the power: A practical approach to goodness-of-fit test for logistic regression models with continuous predictors. Computational Statistics and Data Analysis, 52(5), 2703-2713.

Yamakawa, P., \& Ostos, J. (2013). The influence of the environment on organizational innovation in service companies in Peru. Revista Brasileira de Gestão de Negocios/Review of Business Management, 15(49), 582-600.

Zahra, S. A., \& George, G. (2002). Absorptive capacity: A review, reconceptualization, and extension. The Academy of Management Review, 27(2), 185-203.

Zahler, A., Iacovone, L., \& Mattoo, A. (2014). Trade and innovation in services: Evidence from a developing economy. World Economy, 37(7), 953-979.

\section{Supporting Agencies:}

This research has been financed by Portuguese Public Funds through FCT (Fundação para a Ciência e a Tecnologia) in the framework of the UID/ECO/04105/2013 project.

\section{About the authors:}

1. Aurora A.C. Teixeira, PhD in Science and Technology Policy at Science from the University of Sussex, U.K.E-mail: ateixeira@fep.up.pt

2. Lilian Cristina Bezerra dos Santos, MSc in Services Management, from the University of Porto, Portugal. 


\section{Contribution of each Authors:}

\begin{tabular}{lcc}
\hline Contribution & Aurora Teixeira & Lilian Santos \\
\hline 1. Definition of research problem & $\sqrt{ }$ & $\sqrt{ }$ \\
2. Development of hypotheses or research questions (empirical studies) & $\sqrt{ }$ \\
3. Development of theoretical propositions ( theoretical Work) & $\sqrt{ }$ \\
4. Theoretical foundation/ Literature review & $\sqrt{ }$ \\
5. Definition of methodological procedures & $\sqrt{ }$ \\
6. Data collection & \\
7. Statistical analysis & $\sqrt{ }$ \\
8. Analysis and interpretation of data & $\sqrt{ }$ \\
9. Critical revision of the manuscript & $\sqrt{ }$ \\
10. Manuscript Writing & $\sqrt{ }$ \\
11. Other (please specify which) & $\sqrt{ }$ \\
\hline
\end{tabular}

\section{Notes}

1 'Droege et al. (2009) make a distinction between technologist and assimilation, whereas Djellal et al. (2013) mention an additional (the inversion) approach which emphasises the fundamental role of certain Knowledge-Intensive Business Services (KIBS) in other sectors' innovations.

2 Freel (2005) considers that novel innovation is the new innovation for the industry (both in terms of product and process), and incremental innovation is new only to the company introducing it.

3 Pires et al. (2008) advocate two types of innovation for products: pioneering innovation if the company has introduced a new innovation in the market, i.e., has introduced a product or service that is not a mere imitation of an already existing one; and product innovation, if the innovation introduced is new for the company alone.

4 In their analysis, the authors considered two types of innovation: technological innovation (product innovation + process innovation) and non-technological innovation (organizational and marketing innovation).

5 The authors consider 7 main types of information sources: internal to the company (e.g., know-how, work organization and communication within the company), cooperation relationships (with clients, suppliers, consultants, banks, among others), regional organization of knowledge (e.g., local university and research institutes), regional support organization (e.g., regional association of entrepreneurs and business incubators), financial support organizations (organizations that encourage innovation), national support organizations (e.g., national confederation of Finnish industries and chamber of commerce) and, finally, other external sources of information (e.g., fairs, congresses, internet, media, literature).

6 In this work, Laursen and Salter (2004) created an index to measure the openness of English industrial firms to knowledge from their external environment. Thus, the greater the number of external information sources used by a company, the greater its "openness" to the attraction of this type of knowledge generated from the outside. Since 1996 Portugal has been allocating public funds for the encouraging the professional insertion of $\mathrm{PhDs}$ in companies. However, by 2006 almost $70 \%$ of the companies that had hired their first $\mathrm{PhD}$ failed to apply to any R\&D project managed by Portugal National Innovation Agency (AdI) (Barroca et al., 2015). 